\title{
The Construction of Online Media in Indonesian Artist: Critical Discourse Analysis
}

\author{
Wulansari ${ }^{1}$ \\ \{Wulansari-2019@fib.unair.ac.id $\left.{ }^{1}\right\}$
}

Airlangga University, Surabaya, Indonesia ${ }^{1}$

\begin{abstract}
Discourse analysis has become a significant concern that attracted many recerachers of disciplines to disscuss and generate the theories of their prerspectives. Celebrity life is one of an exciting topic of broadcasting and constructing about news in the online media. The purpose of this study was to determine the analysis of critical discourse analysis. It was focused on how two online media (Republika and JawaPos) which has a different background of news constructing or interpreting about Rina Nose who took off her hijab using Norman Fairclough theory. This research used descriptive qualitative methods for thinking and critical paradigms as viewpoints. The results of this study showed that there were differences in the content of celebrity reporting on two online media content of the text and titles. Each media presented different about Rina's news according to the point background and ideology writer in media.
\end{abstract}

Keywords: Critical Discourse Analysis, Celebrity News, Online Media

\section{Introduction}

Generally, Discourse studies are used to analyze text to understand the message contained. Renkema defines the study of discourse as a scientific discipline that studies the relationship between form and function in the form of verbal communication (both oral and written) [1]. The purpose of the discourse analysis is to explain the convoluted relationship between the elements of the discourse and its function in communication. Discourse analysis is considered critical or known as critical discourse analysis (CDA) due to emphasizing the power constellation that occurs in the process and meaning of production. Besides, Critical discourse analysis is a methodology in a critical paradigm, which can be seen in which the media is not a free and neutral channel. The media are owned by certain groups and used to dominate [2].

Fairclough's theory refers more to a critical appraisal of a news text presentation, especially news presented on online media reporting sites. Critical Discourse Analysis is a unification of text analysis, analysis of the process of production, distribution, and consumption of texts as well as sociocultural analysis of discursive practices. Critical Discourse Analysis contains three dimensions of discourse analysis: the dimensions of the text, discourse practice, and sociocultural practice. First, dimensions of text (microstructural) are analyzed linguistically, by looking at vocabulary, semantics, and syntax. Second, discourse practice (mesostructure) is a dimension related to the process of producing and consuming texts. The last, sociocultural practice (macrostructural) is a dimension related to the outside context of the text [3]. 
Online media can be said as new media using the internet access that can be enjoyed every time using digital devices. Framing messages through text, images, and sounds is the activity to influence the thoughts of audiences. The construction of media is formed in two models: good or bad news model. News is often considered having neutrality quality and agreed authority and cannot be expected to be logical [4]. The values contained in the news reveal the interests of certain communities. This is important because of the news about the picture of reality, delivered the construction of reality that contains non-neutrality. On the other hand, news can be seen through everyone's perspective. The news can be in the form of newspapers and online media. Thus, news can be reviewed through media texts that are reviewed from the viewpoint of the reader and social life. The choice of words used by reporters in a news text is not merely due to chance but also shows how someone's interpretation of facts or reality is based on the ideology they have, so that the news conveyed can attract readers. One of the interesting news for the people in Indonesia is the celebrity's life.

In recent years, the research critical discourse analyses of a celebrity's life using Fairclough study have become a significant concern in online media by many researchers. Analysis of the Fairclough Critical Discourse on Celebrity News in Online Media written by Cenderamata and Darmayanti in 2019 [5] which talked about reporting on the move of Mulan Jameela published by four online media (detik.com, liputan6.com, tempo.co, and tribunnews.com). The aims of this study indicated that there were differences in the content of celebrity reporting in four online media. Each media presents the same news topic with different framing according to the motivation and idealism of the media. Furthermore, the study Analysis of Celebrity News Discourse on Online Media written by Prihantoro in 2013 investigated the news of the arrest of Raffi Ahmad by BNN, on four Online Media (kompas.com, mediaindonesia.com, detik.com, liputan6.com) [6]. Nevertheless, despite presenting popularity and factors studies in celebrity news and showing the good results of their research, a lack of detailed explanation and exploration of each media to investigate the subject research. For this reason, the overarching goal of this study is to address this gap. This study aims to investigate critical discourse analysis using Fairclough theory to analyze Rina Nose who took off her hijab in two online media. Two media (Republika and JawaPos) chosen because of having big structural redaction and company, the writer wanted to know media which has two different background perspective. The first perspective would be shown from Republika.co.id which focuses on the Islamic perspective and JawaPos.com contains general news but it is more focuses on criminal news. The result of this study is to know how two online media construct or interpret news about Rina Nose who took off her hijab.

\section{Research Method}

The method used in this research was a descriptive qualitative method using Fairclough's theory which viewed the text as discourse. In regard, the language in mass media is the reconstruction of journalists. Thus, the approach used was the perspective of Norman Fairclough's critical discourse analysis model, namely the dimensions of the text, discourse practice, and sociocultural practice. Celebrity's life is an interesting topic for many Indonesian people. It can be seen from social media that has been followed by many persons. One of an artist who has many followers of the social media is Nurina Permata Putri or often called by Indonesian people as Rina Nose. Rina was born in Bandung, January 16, 1984. Rina Nose is a multitalented actress, it can be seen that she is a host, singer, and comedian. Supported by 
Rina's social media, such as Instagram followers is 20.4 million [7], followers of the Youtube channel of Rina is 916 million [8], and Twitter of Rina Nose is 895 million [9]. Quoted on page liputan6.com, in 2016 Rina Nose decided to use the hijab every day of her life. But at the end of 2017, Rina Nose became viral on social media because she had taken off her hijab. For this reason, through critical discourse analysis, the researcher can investigate and dissect further how two different backgrounds of media (Republika and JawaPos) constructed Rina Nose who took off the hijab.

The technique of the study had three stages; those were data collection, classification, and analysis. Firstly, the writer sought the media which had a different background in which she wanted to know the perspective of the Islamic-based and general topic-based media; on the other hand, the media had a high impact on Indonesian readers. Then, collecting the news which was related to Rina Nose wears a hijab until took off the hijab. Each media took three news which has a relation to Rina's and analyzed six finding text. The limitation of the data was the text displayed in 2016-2017. The final results of Fairclough's theory were to investigate CDA to different media perspectives of two online media (Republika.co.id and JawaPos.com).

\section{Results and Discussion}

Celebrities are famous people who have prominent profiles in their daily lives. Celebrities are closely related to physicality which is easily recognized and characterized. A celebrity has a big relation with media in which celebrities or artists such as singers, actors, entertainers, or athletes are known for their achievements in certain fields. In addition, celebrities are also seen as individuals who are loved by the general public and have certain advantages or specialties that distinguish them from other individuals. Therefore, celebrity life is often the most topics sought by readers in Indonesia. These online sites have different techniques or ways of presenting news or information that are unique. Every media has a different purpose in every publication of the news. The media has an ideology which is derived from the ideology of the author [5].

The Fairclough's perspective contains three dimensions of discourse analysis, namely the dimensions of the text, discourse practice, and sociocultural practice. First, dimensions of text (microstructural) are analyzed linguistically, by looking at vocabulary, semantics, and syntax. Second, discourse practice (mesostructural) is a dimension related to the process of producing and consuming texts. Third, sociocultural practice (macro structural) is a dimension related to the outside context of the text Also Fairclough has a concern for "language as a social practice" as the idealism of the media in representing news and displaying it in the news text [8]. Based on reading six news on two online media (Republika and JawaPos), there were differences in the presentation of news by displaying positive or negative images of Rina Nose who took off her hijab. The data of the news title about Rina Nose coverage in the media can be seen in the following table and followed by Fairclough's critical discourse analysis framework. 
Table 1. The Data of Rina Nose News

\begin{tabular}{|c|c|}
\hline The Name of Media & Title of News \\
\hline Republika.com & $\begin{array}{l}\text { 1. Free Hijab Problem for Rina Nose, Here's an } \\
\text { Explanation of Rabbani } \\
\text { 2. Indonesian presenter Rina Nose wears a hijab } \\
\text { 3. Wearing Hijab, Rina Nose Delete Old Photos, and } \\
\text { Harvest Praise }\end{array}$ \\
\hline JawaPos.com & $\begin{array}{l}\text { Exited, Rina Nose Suddenly Took off Hijab, This Is } \\
\text { The Reason } \\
\text { Take Off the Hijab, Rina Nose: There is an Inner } \\
\text { Experience That Is Difficult to Explain } \\
\text { This Said Rina Nose After Being Criticized for } \\
\text { Taking off the Hijab }\end{array}$ \\
\hline
\end{tabular}

\subsection{Microstructural Analysis}

The microstructural analysis is based on various language tools used by the media in the coverage of Rina Nose, including two tools representing a person's representation, namely vocabulary; diction (choice of formal and informal vocabulary), euphemistic remarks and grammar; syntactic functions and forms of devotion [5].

Free Hijab Problem for Rina Nose, Here's an Explanation of Rabbani written by Repubika.co.id explained that On this news, Rabani regrets that Rina Nose took off the hijab, and was concerned to see an Indonesian artist who easily used and took off the hijab.

Ridwanul Karim, as Rabbani Promotion Manager, said that the headscarf program for Rina Nose was part of their empathy campaign towards Indonesian artists. He said he wanted to cool the atmosphere that had been heating up because of an argument issued by Rina Nose with one of Ustaz Indonesia [10]..

This part clearly explained that the Islamic background of online media showing the regret condition of the journalist ideology. On the other hand, this article explained how to take advantage of conditions that are more viral through the news of Rina Nose took off the hijab. Besides, the language used at this news cornered Rina Nose's decision. Seeing from vocabulary, semantic and syntax perspective, this article used informally written that used indirect speech. The innovation of words showed as clarification the correct news about Rabbani Company to the news of Rina who took off her hijab.

When linked with the spiritual belief, it shows that Islam is associated with a Muslim woman who wears a hijab. A woman who wears or takes the hijab is something common in Indonesia, in contrast, famous people like Rina Nose who took of her hijab would be perceived as uncommon due to her position as a role model. In contrast, this news did not give the reason why Rina Nose took off the Hijab.

The second part was reported by Repubika.co.id titled "Indonesian Presenter Rina Nose wearing a hijab" [11] and "Wearing the Hijab, Nose Rina Erase Old Photos, and Harvest Praise" [12], this article discussed Rina Nose before taking off the hijab. Republika.co.id is more like reporting news in better articles where this article shows positive journalist writing, this media has a general background that presents all kinds of news such as lifestyle, politics, sports, and crime, but this media is more inclined to Islamic perspective, in other words, this news presented what should have a positive impact on the reader, and when Rina Nose took 
off the hijab, republika.co.id rarely posted the issue. The linguistic field expressed the informal writing of the journalist.

JawaPos.com is one of the big companies which have many kinds of news. The media of Java Pos did not want to be outdone by also reporting news that was viral in 2017 , namely Rina Nose who took off the hijab. There were in the top three most popular those were titled, "Exited, Rina Nose Suddenly Took off Hijab, This Is The Reason", "Take Off the Hijab, Rina Nose: There is an Inner Experience That Is Difficult to Explain", and "This Said Rina Nose After Being Criticized for Taking off the Hijab". In this news, there were more comments from Rina Nose's photos uploaded on her Instagram, from those who used to wear the hijab until suddenly posting photos that did not use the hijab. Many comments from netizens who regretted Rina Nose's decision to remove her hijab. Besides, presenting linguistics that tended to be informal and indirect speech which was taken from comments of the netizens. This news showed that Indonesians care about Rina Nose. Indonesian people's highly desired to know about the decision why she took off her hijab was not answered in this news. Using informal titles gave the impression of being relaxed and interesting to the reader. Besides adverbs used to refer to the past life with a sexy image, then wearing a hijab and excited to take it off again. Unfortunately, these articles did not give the specific reason why Rina Nose took off her hijab.

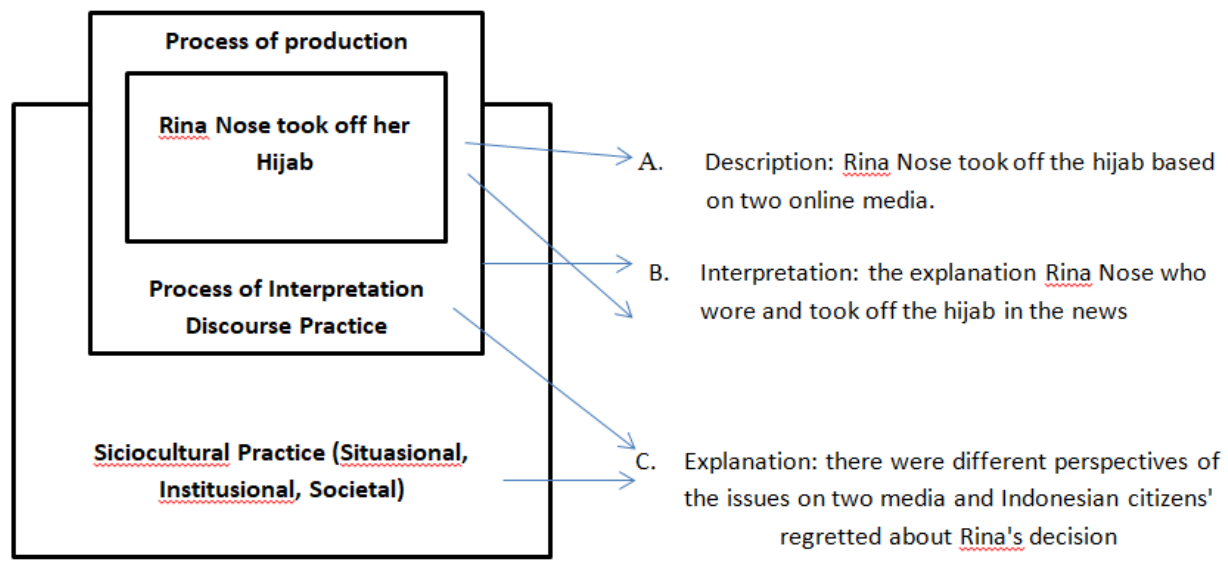

Fig1. The framework of Fairclough analysis in Rina Nose News

The analysis of how the relationship between journalists constructs public by titles and description the news itself based on two online media about Rina Nose shown in table 1 above. The differences between two different backgrounds of media-constructed differently from reporting Rina's news. According to Fairclough's analysis, there were different showing the text, Republika was like to report Rina Nose wore the hijab in 2016 and JawaPos showed Rina Nose took off the hijab in 2017; in contrast, none of the online media gave a specific reason why Rina Nose took off the hijab.

\subsection{Mesostructural Analysis}

In mesostructure dimension analysis, interpretation was carried out on discourse processing, such as the process of spreading and using discourse, media profiles, editor 
procedures, and the way media workers produce texts. Table 2 shows the history of two online media.

Table 2. The Data of Media's History

\begin{tabular}{|l|l|}
\hline \multicolumn{1}{|c|}{ Media Online } & \multicolumn{1}{|c|}{ Histories of Media } \\
\hline www.Republika.co.id & $\begin{array}{l}\text { Republika is one of the Indonesian National daily newspapers. It } \\
\text { is known and described as a publication for Muslim Community. } \\
\text { Founded in 1992 and published the first edition on January 3, } \\
1993 \text { by Yayasan Abdi Bangsa that supported by Ikatan Muslim } \\
\text { Indonesia (ICMI), which was chaired by B.J. Habibi. After he } \\
\text { ceased being president in 1999, and in line with declining of the } \\
\text { ICMI's political role, the majority of ownership was taken } \\
\text { by Mahaka Media in late 2000. Today, Republika is published by } \\
\text { PT Republika Media Mandiri, a subsidiary of Mahaka Media, and } \\
\text { has become a general newspaper [13]. }\end{array}$ \\
\hline www.JawaPos.com & $\begin{array}{l}\text { Jawa Pos (The Java Post) is an Indonesian national daily } \\
\text { newspaper based in Surabaya, East Java. Jawa Pos was launched } \\
\text { by Suseno Tedjo or The Chung Shen on July 1, 1949. The parent } \\
\text { company, "Jawa Pos Group", is owned by Indonesian media } \\
\text { tycoon Dahlan Iskan [14]. }\end{array}$ \\
\hline
\end{tabular}

\subsection{Macrostructural Analysis}

The third dimension is a macro-structural analysis based on the existing opinion of the social context; the media influences how a discourse exists in the media. Socio-cultural practices, such as situational, institutional, and social levels influence media institutions and their discourse. Situational level, related to the production and context of the situation. Institutional level, related to the influence of institutions internally and externally. Social level related to more macro situations, such as political systems, economic systems, and cultural systems of society.

In Rina Nose's news, there was no situational and institutional level found because it did not involve any institution. It can be concluded that the news produced by two online media (Republika and JawaPos) was closely related to the existence of the media itself in raising the issue of Rina Nose as a representation of a celebrity who took off hijab in Indonesia.

Indonesian society, the majority of whom embraced Islam, has created the concept regretting what Rina Nose had done. The public's point of view perceives that a Muslim woman who dresses sexy is bad and covers the entire body or using syar'i outfit is good. Likewise with the coverage of Rina Nose as a celebrity who had a bad image from the viewpoint of the Indonesian people, when she had decided to change her appearance by taking off her hijab. It was then, further being discussed and preached differently depending on the motivations and certain opinions constructed by the two online media.

\section{Conclusion}


This paper concluded that the practice of Ideology has a big role in writing news in media, the meaning of media with a variety of presentations by using certain construction to attract readers. Two online media were clearly different showing the text, Republika was like to report Rina Nose wore the hijab in 2016 and JawaPos showed Rina Nose took off the hijab in 2017. They have a different background of perspective characters and discourses. When viewed from the theory of Fairclough analysis, Rina Nose's news about the hijab became the main object in the theoretical framework of Fairclough. It focused more on how the media described Rina Nose's activities and implemented using online media news titles, text and the Indonesian people were interested in the news because they were curious why Rina Nose decided to take off the hijab. Fairclough is more focused on the reporting text based on each media. Future researchers could focus and try to look for another perspective using three dimensions based on Van Dijk's theory.

\section{References}

[1] Renkema J. Introduction to Discourse Studies [Internet]. 1st ed. amsterdam/philadelphia: John Benjamins Publishing Company; 2004. 374 p. Available from: http://dl241.zlibcdn.com/dtoken/f95e53709396461508f7a8b7898fb652

[2] Eriyanto AW. Pengantar Analisis Teks Media. Yogyakarta LKiS. 2001;

[3] Fairclough N. Critical discourse analysis : the critical study of language / Norman Fairclough. Critical discourse analysis : the critical study of language. 1995.

[4] Bungin B. Penelitian Kualitatif: Komunikasi, Ekonomi, Kebijakan Publik, Dan Ilmu Sosial Lainnya. Kencana. 2011.

[5] Cenderamata RC\&, Darmayanti N. Analisis Wacana Kritis Fairclough Pada Pemberitaan Selebriti Di Media Daring. J Literasi [Internet]. 2019;3(April):1-8. Available from: https://www.researchgate.net/publication/331830467_ANALISIS_WACANA_KRITI S_FAIRCLOUGH_PADA_PEMBERITAAN_SELEBRITI_DI_MEDIA_DARING_F AIRCLOUGH'S_CRITICAL_DISCOURSE_ANALYSIS_OF_CELEBRITY_NEWS _ON_ONLINE_MEDIA

[6] Prihantoro E. Analisis Wacana Pemberitaan Selebriti Pada Media Online. Pros PESAT. 2013;5(0):8-9.

[7] Rina Nose (@rinanose16)・Instagram photos and videos [Internet]. [cited 2020 Jul 13]. Available from: https://www.instagram.com/rinanose16/

[8] (1349) Rina Josscy - YouTube [Internet]. [cited 2020 Jul 13]. Available from: https://www.youtube.com/channel/UCNzpDqNFUv9QcgANzCRMkbw

[9] (21) Nurina Permata Putri (@Rina_Nose) / Twitter [Internet]. [cited 2020 Jul 13]. Available from: https://twitter.com/rina_nose?lang=en

[10] Soal Jilbab Gratis untuk Rina Nose, Ini Penjelasan Rabbani | Republika Online [Internet]. [cited 2020 Jul 13]. Available from: https://www.republika.co.id/berita/senggang/blitz/17/11/23/ozv5fo377-soal-jilbabgratis-untuk-rina-nose-ini-penjelasan-rabbani

[11] Indonesian presenter Rina Nose wears hijab | Republika Online [Internet]. [cited 2020 Jul 13]. Available from: https://republika.co.id/berita/odi1t6414/indonesian-presenterrina-nose-wears-hijab

[12] Berhijab, Rina Nose Hapus Foto Lama dan Panen Pujian | Republika Online 
[Internet]. [cited $2020 \mathrm{Jul}$ 13]. Available from:

https://republika.co.id/berita/odinii280/berhijab-rina-nose-hapus-foto-lama-dan-panenpujian

[13] republika.co.id. Alexa [Internet]. [cited 2020 Jul 13]; Available from: http://www.alexa.com/siteinfo/republika.co.id\#

[14] Jawa Pos Company Profile [Internet]. [cited 2020 Jul 13]. Available from: http://www.jawapos.com/profile/index.php 